\title{
EFFECT OF FETAL CALF SERUM AND MID ESTRUS COW SERUM ON IN VITRO MATURATION AND FERTILIZATION OF OOCYTES FROM CROSSBRED CATTLE IN THE TROPICS
}

\author{
Binoy S. Vettical* \\ Department of Animal Reproduction, Gynaecology and Obstetrics, College of Veterinary and Animal Sciences, Mannuthy, Trichur \\ *Email: binvsren@yahoo.com
}

\begin{abstract}
The objective of the study was to examine the effect of fetal calf serum (FCS) and mid estrus cow serum (ECS) in culture media on in vitro maturation (IVM) and in vitro fertilization (IVF) of oocytes from crossbred cattle in the tropics. Oocytes from abattoir ovaries were cultured in three different maturation media at $39^{\circ} \mathrm{C}$ temperature, $5 \% \mathrm{CO} 2$ tension with maximum humidity for $24 \mathrm{~h}$. TCM-199 containing $25 \mathrm{mM}$ HEPES, $1 \mathrm{mM}$ glutamine $\mathrm{L}, 2.2 \mathrm{mg} / \mathrm{mL}$ sodium bicarbonate, antibiotics, $22 \mu \mathrm{g} / \mathrm{mL}$ pyruvate, $1 \mu \mathrm{g} / \mathrm{mL}$ estradiol $-17 \beta, 0.5 \mu \mathrm{g} / \mathrm{mL}$ FSH and 0.06 IU hCG without serum supplement used as treatment-1 and the above media were further supplemented with $10 \%$ FCS as treatment-2. In treatment-3, instead of $10 \%$ FCS, $20 \%$ heat inactivated ECS (serum collected in mid estrum) was used as serum supplement. Oocytes with maximum degree of cumulus expansion were selected as matured and used for further IVF studies using frozen semen. The IVF medium consisted of Fert-TALP medium supplemented with $1 \mu \mathrm{M}$ epinephrine, $10 \mu \mathrm{M}$ hypotaurine, $20 \mu \mathrm{M}$ pencillamine and $0.56 \mu \mathrm{g} / \mathrm{ml}$ heparin. Culture conditions set for IVF were $39^{\circ} \mathrm{C}$ temperature, $5 \% \mathrm{CO} 2$ tension with maximum humidity. Oocytes showing sperm penetration evidence like presence of enlarged sperm head, male pronuclei with its accompanying sperm tail in the cytoplasm, oocytes with two pronuclei and a clear second polar body but without a sperm tail were considered as fertilized. Significantly higher result of cumulus expansion percentage ( $\mathrm{p}<0.05$ ) was observed when oocytes matured in media supplemented with FCS as compared to other two treatments. There was no influence of source of serum in maturation media on further IVF of matured oocytes in this study.
\end{abstract}

Keywords: Cross bred cattle; Oocytes; Fetal Calf Serum; Estrus Cow Serum; In vitro maturation; In vitro fertilization

\section{Introduction}

TCM-199 is the most commonly used in vitro maturation (IVM) medium for cattle oocytes. Either HEPES buffered TCM-199(Khurana and Niemann, 2000) or bicarbonate buffered TCM-199 (Neglia et al., 2003) was used for IVM of bovine oocytes. TCM-199 is a complex medium and it contains vitamins, amino acids, purines and other substances. Hormones, Sera and granulose cells are the common additives used to improve the IVM of oocytes (Gordon, 2003). Bovine serum has been used as the main protein source in maturation media for cattle IVM and in vitro fertilization (IVF) studies.

Younis et al. (1989) reported that estrus cow serum (ECS) collected at proestrus was judged superior than fetal calf serum (FCS). Other investigators observed no differences between the two sources of serum (Fukui and Ono, 1989). Gordon (2003) reported that ECS had a significant and marked effect compared with FCS on the developmental competence of bovine oocytes. In contrary, Puri et al. (2015) obtained higher maturation rate for buffalo oocytes in the presence of fetal bovine serum (FBS) as compared to estrus buffalo serum (EBS). The objective of the present study was to examine the effect of FCS and mid ECS in culture media on IVM and IVF of oocytes from crossbred cattle under tropical conditions.

\section{Methodology}

Ovaries from crossbred cattle of Kerala were used for this study. A total of 2160 culture grade oocytes aspirated from abattoir ovaries were grouped into three treatment groups. Culture grade oocytes were cultured in TCM-199 containing $25 \mathrm{mM}$ HEPES, $1 \mathrm{mM}$ glutamine $\mathrm{L}, 2.2 \mathrm{mg} / \mathrm{mL}$ sodium bicarbonate, antibiotics, $22 \mu \mathrm{g} / \mathrm{mL}$ pyruvate, $1 \mu \mathrm{g} / \mathrm{mL}$ estradiol- $17 \beta, 0.5 \mu \mathrm{g} / \mathrm{mL}$ FSH and $0.06 \mathrm{IU}$ hCG without serum supplement as treatment-1 $(\mathrm{n}=720)$ and in treatment-2(n=720) the above media were further supplemented with $10 \%$ FCS. In treatment-3 ( $n=720)$, instead of $10 \%$ FCS, $20 \%$ heat inactivated ECS (serum collected in mid estrum) was used as serum supplement. Culture conditions set for this study were $39^{\circ} \mathrm{C}$ temperature, $5 \% \mathrm{CO}_{2}$ tension with maximum humidity. After $24 \mathrm{~h}$ culture 
in maturation medium, oocytes were classified based on the degree of cumulus cell expansion as per the classification of Hunter and Moore (1987) and oocytes with maximum degree of cumulus expansion (Grade 1) were selected for further IVF studies. The IVF medium consisted of FertTALP medium supplemented with $1 \mu \mathrm{M}$ epinephrine, $10 \mu \mathrm{M}$ hypotaurine, $20 \mu \mathrm{M}$ pencillamine and $0.56 \mu \mathrm{g} / \mathrm{ml}$ heparin (Khurana and Niemann, 2000). Motile sperms from frozen semen were separated by percoll gradient separation and used for IVF. The final concentration in fertilization droplet was adjusted to 15,000 to 20,000 sperms per oocytes. Matured oocytes from each treatment group after washing were loaded gently into separate IVF drops and allowed to complete incubation for a period of $24 \mathrm{~h}$ without any disturbance in the culture conditions. Culture conditions set for IVF were $39^{\circ} \mathrm{C}$ temperature, $5 \% \quad \mathrm{CO}_{2}$ tension with maximum humidity. Oocytes after 24 hour culture in fertilization medium were denuded and evaluated for evidence of sperm penetration. Oocytes showing sperm penetration evidence like presence of enlarged sperm head, male pronuclei with its accompanying sperm tail in the cytoplasm, oocytes with two pronuclei and a clear second polar body but without a sperm tail were considered as fertilized. Oocytes were stained with $1 \%$ orcein in $45 \%$ acetic acid. All the oocytes stained as above were examined under bright field of inverted phase contrast microscope at $200 \mathrm{X}-400 \mathrm{X}$ magnifications for evidence of sperm penetration. The effect of ECS and FCS on the yield of matured and fertilized oocytes was assessed. Data on fertilization rate was statistically analyzed with one way ANOVA. P-value of less than 0.05 was considered statistically significant.

\section{Results}

The cumulus cell expansion rate obtained was 5.52 \pm 1.8 , $65.3 \pm 2.6$ and $48.7 \pm 2.7$ for treatment 1,2 , and 3 respectively. There was significant difference observed between these three treatment groups $(\mathrm{P}<0.05)$. IVM using culture media containing $10 \%$ FCS showed significantly higher results when compared to IVM using media supplemented with mid ECS, followed by media without serum supplement $(\mathrm{P}<0.05)$. Fertilization rate obtained was $25.0 \pm 1.7,27.7 \pm 1.7$ and $22.9 \pm 2.5$ for matured oocytes from treatment 1,2 , and 3 respectively. There was no significant difference noticed between these three treatment groups in fertilization rate after oocyte maturation $(\mathrm{P}<0.05)$.

\section{Discussion}

Serum was known to contain a wide range of components like hormones, growth factors, amino acids and binding proteins (Gordon, 2003). Growth factors important for cytoplasmic maturation such as epidermal growth factor and IGF-I were found in serum (Mikkelsen, 2004). Several protein complements are important for cellular modifications and growth in various living systems that upkeep the interactions with cellular proliferation and MAPK networks (Sreenivas et al., 2012).

Some investigators observed no differences between FCS and ECS to support maturation of oocytes in vitro (Fukui and Ono, 1989). Studies in Ireland showed that ECS had a significant and marked effect compared with FCS on subsequent developmental competence of oocytes. Some studies suggesting that proestrus cow serum might be more effective in maturation of oocytes than ECS; analysis of the serum showed high levels of Luteinizing Hormone (LH) and prolactin (Gordon, 2003). Addition of buffalo follicular fluid and Fetal Bovine Serum (FBS) at different fraction, are effective maturation medium, as they encouraged the development of high quality matured bovine oocytes (Momozawa and Fukuda, 2011). In a study, Karami et al. (2011) achieved better rates of IVM, IVF and embryo development of ovine oocytes when basic media supplemented with, estrus sheep serum and estrus goat serum. In contrary, the rate of oocyte development was shown improved in the presence of FBS during in vitro production of sheep oocytes by Abolfazl et al. (2012). Sreenivas et al. (2013) achieved better maturation and cleavage when FBS supplemented in IVM and IVF media. Also Puri et al. (2015) obtained higher maturation rate for buffalo oocytes in the presence of FBS as compared to Estrus Buffalo Serum (EBS). Similar results were obtained in the present study conducted using crossbred cattle oocytes. The ECS used in the present study was collected mid in estrum.

Serum provides a wide variety of macromolecular proteins, low molecular weight nutrients, carrier proteins for water insoluble components, and other compounds necessary for in vitro growth of cells, such as hormones and attachment factors. The hormones and other components in ECS may vary with the stage of estrum. Workers who have quantified the changes in peripheral plasma concentrations during the bovine estrus cycle recorded that estradiol levels can increase threefold from a basal value of $5 \mathrm{pg} \mathrm{ml}$ to a peak value of $15 \mathrm{pg} \mathrm{ml}$ on the day of estrus; the peak concentration of LH also occurs around the time when estradiol is at its peak level (Gordon, 2003). Exactly finding the stage of estrum in cattle is also a difficult task and this might go some way in explaining why varying results with ECS in maturation of oocytes in different studies.

In conclusion, as per the present study FCS is found to be superior to ECS on IVM of oocytes from crossbred cattle in the tropics and there is no influence of source of serum in maturation media on further IVF of matured oocytes.

\section{Competing Interests}

Declare that there is no competing interest.

\section{Acknowledgment}

I am grateful to Dr. E. Nanu, Dean, College of Veterinary and Animal Sciences, Mannuthy, Kerala Agricultural University for 
the facilities provided for the research work. I express my sincere thanks to Dr. T. Sreekumaran Professor and Head (Rtd) and Dr. V. Vijayakumaran, Professor and Head, Department of Animal Reproduction, Gynaecology and Obstetrics for their valuable guidance.

\section{References}

Abolfazl S, Mohammad AA, Ebrahim A, Hassan N, Morteza M and Banafsheh H (2012) The effect of macromolecule source and type of media during in vitro maturation of sheep oocytes on subsequent embryo development. $J$. Reprod. Infertil. 13(1): 13-19.

Fukui Y and Ono H (1989) Effects of sera, hormones and granulose cells added to culture medium for in vitro maturation, fertiliuzation, cleavage and development of bovine oocytes. J. Reprod. Fert. 86: 501-506. DOI: 10.1530/jrf.0.0860501

Gordon I (2003) Laboratory Production of Cattle Embryos (2 ${ }^{\text {nd }}$ edition). CABI publishing, Oxon, UK. p.548. DOI: 10.1079/9780851996660.0000

Hunter AG and Moor RM (1987) Stage-dependent effects of inhibiting ribonucleic acids and protein synthesis on meiotic maturation of bovine oocytes in vitro. J. Dairy Sci.70: $\quad 1646-1651 . \quad$ DOI: $10.3168 /$ jds.S00220302(87)80192-3

Karami SH, Sarsaifi K and Mehrannia T (2011) In vitro maturation of ovine oocytes using different maturation media: Effect of human menopausal serum. J. Assist. Reprod. Genet. 28(6): 531-537. DOI: 10.1007/s10815-010-9523-3

Khurana NK and Niemann H (2000) Effect of cryopreservation on glucose metabolism and survival of bovine morulae and blastocysts derived in vitro or in vivo. Theriogenology 54: 313-326. DOI: 10.1016/S0093-691X(00)00351-4
Mikkelsen AL (2004) In vitro maturation of human ova. International Congress Series 1266: 160-166. DOI: 10.1016/j.ics.2004.02.086

Momozawa K and Fukuda Y (2011) Effects of fractions of bovine follicular fluid and fetal bovine serum as supplements to maturation medium on in vitro development of in vitro fertilized bovine embryos. J. Mamm. Ova Res. 28(1): 6874. DOI: $10.1274 /$ jmor. 28.68

Neglia G, Gasparrini B, Di Brienza VC, Di Palo R, Campanile G, Presicce GA and Zicarelli L (2003) Bovine and Buffalo in vitro embryo production using oocytes derived from abattoir ovaries or collected by transvaginal follicle aspiration. Theriogenology 59: 1123-1130. DOI: 10.1016/S0093-691X(02)01170-6

Puri G, Chaudhary SS, Singh VK and Sharma AK (2015) Effects of fetal bovine serum and estrus buffalo serum on maturation of buffalo (Bubalus bubalis) oocytes in vitro. Veterinary World 8(2): 143-146. DOI: 10.14202/vetworld.2015.143-146

Sreenivas D, Kaladhar DS, Samy AP and Kumar RS(2012) Understanding mechanism of in vitro maturation, fertilization and culture of sheep embryos through insilico analysis. Bioinformation 8(21): 1030-1034. DOI: 10.6026/97320630081030

Sreenivas D, Kaladhar DS, Yarla NS, Thomas VM and Palnisamy A (2013) Effect of protein supplementation on in vitro maturation of sheep oocytes and in vitro culture of preimplantation with $\alpha$-tocopherol supplementation in CR1aa medium on sheep embryos to the blastocyst stage. J. Allergy Ther. 4: 133. DOI: 10.4172/2155-6121.1000133

Younis AI, Bracket BG and Fayrer-Hosken RA(1989) Influence of serum and hormones on bovine oocyte maturation and fertilization in vitro. Gam. Res. 23: 189-201. DOI: 10.1002/mrd.1120230206 